\title{
Fen Bilimleri Öğretim Programına Yönelik Öğretmenlere Verilen Hizmet İçi Eğitimin Öğretmen Görüsslerine Göre Değerlendirilmesi ${ }^{1}$
}

DOI: $10.21666 /$ muefd.331479

\author{
Ulaş KUBAT ${ }^{2}$ \\ Muğla Sıtkı Koçman Üniversitesi, Eğitim Fakültesi \\ ulaskubat@mu.edu.tr
}

$\ddot{\text { Ozet }}$

Fen bilimleri öğretmenlerinin bilgi, beceri ve tutumlarının geliștirilmesine yönelik diğer bir deyişle mesleki gelişim için öğretmenlerin alacağ hizmet içi ĕgitim vazgeçilmez bir unsurdur. Öğretim programı uygulamaya konulmadan önce ögretmenlere programin temel felsefe ve vizyonun tanitılması, programın kazanım, içerik, öğretme-öğrenme süreci ve ölçme-değerlendirme boyutlarının sistematik bir şekilde tanıtımının yapılması bir gerekliliktir. Bu çalışmanın amacı fen bilimleri öğretmenlerine verilen öğretim programına yönelik hizmet içi eğitimi öğretmen görüşlerine göre değerlendirmektir. Bu araştırmada veri toplama yöntemi olarak yart yapılandırılmış görüşsme tekniği kullanılmıştır. Araştırmada Muğla ilinde 16 Fen Bilimleri öğretmeni ile görüş̧me yapılmıştır. Araştırmanın sonucunda elde edilen bulgulara göre görüş̧meye katılan 16 öğretmenden hiç birisi fen bilimleri öğretim programına yönelik hizmet içi eğitim almadığını belirtmiştir. Yapılan hizmet içi eğitimlerin kendileri için verimsiz olduğunu ve hizmet içi eğitimlerin sadece süre doldurmak amacı ile yapıldığını belirtmişlerdir. Ayrıca öğretmenlerin hizmet içi eğitime katılmaya isteksiz olduklarını, yapılan hizmet içi eğitimin köklü değişime ihtiyaç duyulduğunu belirtmişlerdir.

Anahtar Sözcükler: Hizmet içi eğitim, Fen bilimleri öğretim programı, Fen bilimleri öğretmeni

\section{Evaluation of The In-Service Training Program Given About The Science Education Curriculum on The Basis of The Teachers' Opinions}

\begin{abstract}
In-service training is indispensable for science education teachers in order to improve their information, skills and manners; in other words, for their professional development. The main idea and vision of the teaching curriculum should be introduced to teachers before its implementation. It is necessary to introduce the advantages, content, the process of teaching and learning, assessment and evaluation systematically again before the implementation of the teaching curriculum. The aim of the present study is to evaluate the in-service training for the teaching curriculum according to science teachers' views. As for data gathering method, this study employs the tools of semi-structured interview. I interviewed with 16 science teachers in the city of Muğla. All of the participants admitted that they had not participated in any in-service training for science education curriculum. They expressed that the in-service trainings are not efficient and they are just time-consuming. They also stated the need for substantial restructuring since their colleagues are reluctant in participating in those in-service trainings in their present format.
\end{abstract}

Keywords: In-Service Training, Science Curriculum, Science Teacher

Fen bilimleri öğretmenlerinin bilgi, beceri ve tutumlarını geliştirmeye yönelik hizmet içi eğitimler mesleki gelişimleri için çok önemlidir. Fen bilimleri öğretim programının uygulayıcısı olan öğretmenlere tanıtımının yapılması ve programa yönelik uygulama örneklerinin hizmet içi eğitimde ögretmenlerle ortak bir paylaşıma gidilmesi, programın kazanımlarının gerçekleşmesi için büyük önem taşımaktadır. Verilecek olan hizmet içi eğitimde sınıf yönetimi, materyal hazırlama ve kullanımının yanı sıra öğrenci merkezli öğretim yöntemleri, kazanımları gerçekleştirmeye uygun etkinlik düzenlenmesi

\footnotetext{
${ }^{1}$ Bu çalışma yazarın 2015 yılında hazırladı̆̆ı yayınlanmamış doktora tezinin bir bölümünü içermektedir.

2 Öğr. Gör. Dr. Muğla Sıtkı Koçman Üniversitesi, e-posta: ulaskubat@yahoo.com

$\mathrm{Bu}$ araştırmada elde edilen bulgular 12-14 Kasım 2015 tarihleri arasından düzenlenen "Felsefe, Eğitim ve Bilim Tarihi” adlı sempozyumda sözlü bildiri olarak sunulmuştur
} 
ve öğrenmede bireysel farklılıkların dikkate alınmasının önemin vurgulanması programın başarısı için önemlidir. Ayrıca fen bilimleri öğretmenlerinin bilgi, beceri ve tutumlarının geliştirilmesine yönelik diğer bir deyişle mesleki gelişim için öğretmenlerin alacağı hizmet içi eğitim vazgeçilmez bir unsurdur. Yaşam boyu eğitimin vazgeçilmez bir parçası olan hizmet içi eğitim, ve tutumlar kazandırmayı amaçlamaktadır (Mc Dermott ve diğerleri, 2001: 219).

Hizmet içi eğitimlerde sadece programın tanıtılmasından öte, fen bilimleri öğretmenlerinin programa yönelik bilgi, beceri ve tutum kazandırılması çok önemlidir. Çünkü programın uygulayıcı olan öğretmenin yeni fen bilimleri öğretim programı hakkında bilgi ve beceri kazandıkça programı tanıyıp benimseyecek ve böylelikle programın daha kolay uygulamaya konulması sağlanabilecektir. Kısacası program uygulamaya konulmadan önce öğretmenlere programın temel felsefe ve vizyonun tanıtılması, programın kazanım, içerik, öğretme-öğrenme süreci ve ölçme-değerlendirme boyutlarının sistematik bir şekilde tanıtımının yapılması bir gerekliliktir. Program konusunda fen bilimleri öğretmenlerine yönelik bilgi, beceri ve tutum geliştirmenin yanı sıra programın tanıtımının yapıldığı uygulamalı bir hizmet içi eğitim olanağı sunulmamasının fen bilimleri öğretim programı için büyük eksiklik olduğu söylenebilir.

Programının öğeleri olan kazanım, içerik, öğretme-öğrenme süreci ve değerlendirme boyutlarının bu programın uygulayıcısı olan öğretmen tarafından hizmet içi eğitimde incelenerek özümsenip uygulamaya hazır hale getirilmesi verimli ve kalıcı bir öğrenme için bir gerekliliktir. Öğretim sürecinin başarılı olması nitelikli ve planlı bir hizmet içi eğitime bağlıdır. Bu bağlamda kazanımları gerçekleştirmeye yönelik hangi yöntem, teknik ve öğretim stratejileri kullanılacağı ve başarının nasıl değerlendirileceğini içeren kapsamlı bir hizmet içi eğitim öğretim sürecinde önemli bir yere sahiptir.

\begin{abstract}
Amacı
Günümüzde bilim ve teknolojideki hızlı değişim eğitim programlarının yanı sıra, kazanımları, öğretim metotlarını ve öğretmenlerin derslerini nasıl işlemesi gerekliliğini etkilemektedir. Dolayısı ile öğretmenlerin hizmet öncesi eğitimlerinin yanı sıra hizmet içi eğitimlerinin gereğinin çok önemli olduğu açıkça gözükmektedir (Erişen, 1998: 41). Öğretmenlerin hizmet öncesi eğitimleri sonrası mesleklerinin gerektirdiği bilgi, beceri ve tutumlarını geliştirmesine yönelik düzenli hizmet içi eğitim almaları kendilerini sürekli geliştirmeleri açısından çok büyük önem arz etmektedir. Bu çalışmanın amacı, fen bilimleri öğretim programına yönelik fen bilimleri öğretmenlerine verilen hizmet içi eğitimi öğretmen görüşlerine göre değerlendirmektir.
\end{abstract}

\title{
YÖNTEM
}

$\mathrm{Bu}$ araştırmada nitel araştırma yöntemi kullanılmış olup olgu bilim desene göre tasarlanmıştır. Nitel araştırmada olaylar derinlemesine ve detaylı incelenmesini amaçlayan, veri toplama aracı olarak genellikle görüşmeler, gözlem, alan notları ve açık uçlu sorular kullanılarak sonuçlar istatiksel raporlardan daha çok açıklamalı anlatımla katulımcılardan direk alıntılara dayandırılır (Johson ve Christensen, 2012). Olgubilim araştırmasında araştırmacı birey veya grup ile yakın ve uzun görüşmeler yaparak farkında olunan yada olunmayan olgular hakkında yeni bilgiler elde etmeye çalışır (Gürbüz, Şahin, 2014). Araştırmanın evreni; 2014-2015 eğitim ve öğretim yılında Muğla ili ve ilçelerindeki tüm orta okullarındaki Fen Bilimleri öğretmenlerinden oluşmaktadır. Araştırmanın nitel verileri üç farklı gruptan elde edilmiştir. Araştırmanın öğretmen örneklemi belirlenmesinde ilçe bazında Muğla ili alt, orta ve üst gelişmişlik düzeyine göre ilçelerden iki kadın iki erkek toplam her ilçeden dört öğretmen olmak üzere Muğla Merkez, Ula, Yatağan ve Kavaklıdere ilçelerinden toplam 16 öğretmen tesadüfi olarak seçilerek amaçlı örnekleme yöntemlerinden maksimum çeşitlilik örnekleme yöntemi kullanılmıştır. Araştırmada kullanılan soruların yanıtlarını bulabilmek amacıyla, Muğla ilinde 16 Fen Bilimleri öğretmeni ile görüşme yapılmıştır. Onaltı öğretmenin her birisi ile yaklaşık yirmi dakika süren görüşme yapılıp görüşme yapılan fen bilimleri öğretmenlerinden gerekli izinler alınarak yapılan görüşmeler ses kayıt cihazı ile kaydedilmiştir. Bu araştırmada veriler, yarı yapılandırılmış görüşme tekniği kullanılmıştır. Fen Bilimleri öğretmenleri ile yapılan görüşmelerden elde edilen veriler araştırmacı ve diğer bir fen eğitimcisi tarafından kodlandıktan sonra, yapılan hesaplamalar sonucu kodlayıcılar arası uyuşum yüzdesi \%84,61 olarak hesaplanmıştır. Bu amaçla Miles ve Huberman'ın (1994) güvenirlik formülü kullanılmıştır. 
$\mathrm{P}=\mathrm{Na}($ Görüş Birliği)/ Na (Görüş Birliği) + Nd (Görüş Ayrıllğı)X100 (Miles ve Huberman 1994).

Uyuşum yüzdesi $\% 84,61$ dır. Uyuşum yüzdesi $\% 80$ veya daha büyük olan değerler kabul edilebilir alınır. (Neuendorf akt.Yürük, 2005) O halde bu araştırma için kodlayıcılar arası uyuşum yüzdesi kabul edilebilir bir değerdir. Verilerin analizinde kodlar oluşturularak, elde edilen veriler betimsel analiz kullanılarak çözümlenmiştir. Betimsel analizde elde edilen bulgular katılımcılardan doğrudan alıntılar yolu ile düzenlenip yorumlanarak okuyucuya sunulur (Yıldırım, Şimşek,2013). Görüşmeye katılan Fen Bilimleri öğretmenleri Ö1, Ö2, Ö3...Ö16 olarak kodlanmış olup örneğin Ö1 görüşmeye katılan birinci öğretmeni, Ö4 dördüncü öğretmeni, Ö 12 on ikinci öğretmeni temsil etmektedir.

\section{Çizelge 1.Nitel veri grubuna yönelik öğretmen dağılımı}

\begin{tabular}{|c|c|c|}
\hline OKULUN BULUNDUĞU YER & FREKANS & $\%$ \\
\hline Menteşe & 4 & 25 \\
\hline Yatağan & 4 & 25 \\
\hline Kavaklıdere & 4 & 25 \\
\hline Ula & 4 & 25 \\
\hline TOPLAM & 16 & 100 \\
\hline \multicolumn{3}{|l|}{ CINSSIYET } \\
\hline Kadın & 8 & 50 \\
\hline Erkek & 8 & 50 \\
\hline \multicolumn{3}{|l|}{ YAŞ GRUBU } \\
\hline $21-25$ & 1 & 6,3 \\
\hline $26-30$ & 6 & 37,5 \\
\hline $31-35$ & 5 & 31,3 \\
\hline $36-40$ & 2 & 12,5 \\
\hline $41-45$ & 2 & 12,5 \\
\hline \multicolumn{3}{|l|}{ ÖĞRENIMM DÜZEYİ } \\
\hline Lisans & 13 & 81,3 \\
\hline Yüksek Lisans & 3 & 18,8 \\
\hline \multicolumn{3}{|l|}{ HIZMET YILI } \\
\hline $1-5$ & & 37,5 \\
\hline $6-10$ & & 18,8 \\
\hline $11-15$ & & 25,0 \\
\hline $16-20$ & & 6,3 \\
\hline $21-25$ & & 12,5 \\
\hline \multicolumn{3}{|c|}{$\begin{array}{l}\text { MEZUN OLUNAN YÜKSEKÖĞRETIM } \\
\text { KURUMU }\end{array}$} \\
\hline Eğitim Fakültesi & 16 & 100 \\
\hline \multicolumn{3}{|l|}{ HİZMET İÇí EĞíTíM } \\
\hline Hayır & 16 & 100 \\
\hline
\end{tabular}

Görüşme yapılan öğretmenlerin hepsi eğitim fakültesi mezunu olup, fen bilimleri öğretim programına yönelik hizmet içi eğitim almamıştır. Görüşme yapılan öğretmenlerin dörtte biri 11-15 yıl hizmete sahip iken, sekizde biri 21-25 yıl hizmete sahiptir. Öğretmenlerin \%37,5'i 1-5 yı1, \%18,8 6-10 y1l ve çok azı 16-20 y1l hizmete sahiptir. Katılımcıların \%81,3'ü lisans mezunu, \%18,8'i yüksek lisans mezunudur. Buna göre görüşme yapılan öğretmenlerin çoğunluğu lisans mezunudur. Öğretmenlerin yaklaşık üçte biri 31-35 yaş, sekizde biri 36-40, yine sekizde biri 41-45, \%37,5'i 26-30 ve çok azı da 21-25 yaş grubu arasıdır. Görüşme yapılan öğretmenlerin yarısı kadın, yarısı erkektir.

\section{Veri Toplama Aracı}

Araştırmanın nitel verilerini elde etmeye yönelik görüşme formu yarı yapılandırılmış taslak olarak hazırlanmıştır. Yarı yapılandırılmış görüşme tekniğinde, araştırmacının görüşme soruları önceden 
hazırladığı fakat görüşme boyunca esnek bir şekilde soruların yeniden düzenlenmesine imkan veren bir tekniktir (Ekiz, 2009:63). Görüşme soruları da literatürde (Varış,1996; Erden,1998; Ertürk, 1994;Orsntein ve Hunkins 2004; Sönmez, 2008; Demirel, 2010; Uşun 2012) program değerlendirmede yanıt aranacak sorulara yönelik ölçütler dikkate alınarak belirlenmiştir. Dört eğitimde program geliştirme ve ölçme değerlendirme uzmanı, dört fen bilimleri öğretmenin görüşleri uzman görüşü olarak alınıp, iki fen bilimleri öğretmeni ile soruların anlaşılır olup olmadığına ve cevapların araştırma sorularına uygunluğuna yönelik deneme görüşmesi yapılmıştır. Bu süreç sonunda görüşme formu kapsamı tekrar incelenip düzenlenmiş ve uygulamaya hazır hale getirilmiş̧ir. Fen Bilimleri öğretmenleri ve öğretim üyelerinin görüş ve önerileri doğrultusunda yarı yapılandırılmış görüşme soruları hazırlanmış, öğretmenlerin kazanımlarla ilgili görüşleri ve değerlendirmeleri detaylı bir biçimde tespit edilmeye çalışılmıştır.

\section{BULGULAR}

Bu kısımda fen bilimleri öğretim programına yönelik fen bilimleri öğretmenlerine verilen hizmet içi eğitim öğretmen görüşlerine göre değerlendirilerek öğretmenler ile yapılan görüşmelerden elde edilen verilere ilişkin bulgulara yer verilmiştir.

\section{1.Öğretmenlerin "yeni fen bilimleri programı için öğretmenlere verilen hizmet içi eğitimin ne gibi yararları vardır?" sorusuna verilen yanıtlara ilişkin bulgular}

Öğretmenlere yöneltilen "yeni fen bilimleri programı için öğretmenlere verilen hizmet içi eğitimin ne gibi yararları vardır?" sorusuna ait yanıtların kod ve frekansları Çizelge 2'de gösterilmektedir.

\section{Çizelge2.Yeni fen bilimleri programı için öğretmenlere hizmet içi eğitime ilişkin kodlar}

\begin{tabular}{|c|c|c|c|}
\hline \multirow{10}{*}{$\frac{\mathfrak{z}}{\mathrm{J}}$} & & FREKANS & ÖĞRETMENLER \\
\hline & Hizmet İci Eğitimin Yararları & & \\
\hline & Güvenle derse girme & 4 & Ö1,Ö2,Ö3,Ö9 \\
\hline & Eksikliklere cevap bulma & 3 & Ö1,Ö6,Ö9 \\
\hline & Üniversite ve hizmet içi eğitim & 3 & Ö1,Ö13,Ö14 \\
\hline & Soru cevap şeklinde & 3 & Ö4,Ö5,Ö8 \\
\hline & Bakış açıs1 geliştirme & 2 & Ö6,Ö9 \\
\hline & Programı öğrenme şans1 & 1 & Ö14 \\
\hline & Sinıfta uygulama şansı & 1 & Ö14 \\
\hline & Öğrenci hazırbulunuşluğu & 1 & Ö15 \\
\hline
\end{tabular}

\section{Kategori}

\section{Hizmet İçi Eğitimin Yararları}

Çizelge 2'de görüldüğü gibi Araştırmaya katılan öğretmenlerin dörtte biri (4) yeni programa yönelik hizmet içi eğitim verilmesi durumunda kendinden daha emin şekilde derslerine gireceklerini, hizmet içi eğitimde merak edilenlere, eksikliklere cevap bulunabileceği, verilen hizmet içi eğitimler yerine üniversitelerin bu eğitimi vermesinin faydalı olacağını ve soru cevap şeklinde uygulamalı hizmet içi eğitimin yararlı olabileceğini, öğretmenlerin bakış açılarını geliştireceğini, hizmet içi eğitimde öğrendiklerini sınıflarında uygulama şansı yakalayacaklarını, öğrencilerin seviyelerine inmelerini kolaylaştıracağınıvurgulamışlardır. Bu konudaki görüşlerini aşağıdaki gibi ifade etmişlerdir:

"Hizmet içi eğitimler olsa iyi olur, özellikle üniversite kanalı ile aldığımız eğitimler daha eğlenceli oluyor. Daha önce katıldım üniversite bünyesinde yapılmış olan bu tip çalışmalara. Bu işi üniversitelere bıraksalar çok memnun oluruz. Gerçekten üniversiteler mevcut 1hhh Milli Eğitim Sisteminden bir adım önde.”(Ö1)

"Yani işlerken öğreniyorum yeni programı. Bana bir hizmet içi eğitim kursu verilse idi, hangi konu nereye kaymış niçin, ne kadar azaltılmış veya kazanımı ne duruma gelmiş diye bir hizmet içi eğitim kursu verilse idi, daha bilinçli, daha bilerek girerdim. Ben şimdi bir sene, iki sene, üç sene sekize kadar bu yeni müfredat uygulanana kadar öğretirken öğreneceğim. O sıkıntımız var yani. Öncesinden verilse idi ben daha rahat daha güvenli girerdim dersime.”(Ö2) 


\section{2.Öğretmenlerin "yeni fen bilimleri programı için öğretmenlere verilen hizmet içi eğitimdeki sorunlar nelerdir?” sorusuna verilen yanıtlara ilişkin bulgular}

\section{Hizmet İçi Eğitimdeki Sorunlar}

Çizelge3.Hizmet içi eğitimdeki sorunlara ilişkin kodlar

\begin{tabular}{|c|c|c|c|}
\hline \multirow{8}{*}{ 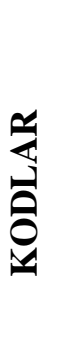 } & & FREKANS & ÖĞRETMENLER \\
\hline & Hizmet İçi Eğitimdeki Sorunlar & & \\
\hline & Süre doldurma & 4 & Ö4,Ö5,Ö13,Ö14 \\
\hline & Hizmet içi eğitim ihtiyacı & 2 & Ö1,Ö9 \\
\hline & Değişim ihtiyacı & 1 & Ö13 \\
\hline & Katılım isteksizliği & 1 & Ö14 \\
\hline & Çözümsüzlük & 1 & Ö1 \\
\hline & Ders kitabındaki yanlışlıklar & 1 & Ö1 \\
\hline
\end{tabular}

Çizelge 3’te görüldüğü gibi araştırmaya katılan öğretmenlerin dörtte biri (4) verilen hizmet içi eğitimlerin verimsiz geçtiğini, sadece süre doldurmak için yapıldığını, iki öğretmen öğretmenlerin hizmet içi eğitime ihtiyac1 olduğunu, bir öğretmen öğretmenlerin hizmet içi eğitime katılmak istemediğini ve bir öğretmen de Milli Eğitim Bakanlığının yapmış olduğu hizmet içi eğitimin çok büyük revizyona ihtiyacı olduğunu belirtmiştir:

"Çünkü on tane hizmet içi eğitim verilirse bunların ancak iki tanesi faydalı oluyor. Onun dışında yapılan işlem CD' yi tak ordan bir kişi okusun süre doldurmak yani. Onun dışında soru cevap şeklinde uygulama şeklinde bir hizmet içi eğitim oluşmuyor. Sadece yapılmış olması için yapılıyor bunlar. Onun için hani ben hizmet içi eğitim alsak da orda faydalı bir şeyler bize anlatılacağını düşünmüyorum.’'(Ö4)

"Ben bakanlığın yapmış olduğu üç tane hizmet içi eğitime katıldım. Ama çok büyük düzenlemeye ihtiyaç var. .. Akademik camianın aktardığı yeni gelişmeleri düzenlemeye ihtiyaç var. Bürokrasinin kendi içindeki yaşadığı sıkıntıları bütünleştirerek dizayna ihtiyacı var diye düşünüyorum. Verimsiz geçiyor yani şu noktada söyliyim ben hangi hizmet içi eğitime gittiysem daha sonra kendimi geliştirmeye hissederek geldim. Yani bir ölçme değerlendirmeye gittiysem döndüğümde mutlaka ekstra sağdan soldan yaptığım siparişlerle mesela kitap okuyarak geliştirme ihtiyacı duydum.”(Ö13)

\section{3.Öğretmenlerin "yeni fen bilimleri programı için öğretmenlere hizmet içi eğitim nasıl olmalıdır?" sorusuna verilen yanıtlara ilişkin bulgular}

Öğretmenlere yöneltilen "yeni fen bilimleri programı için öğretmenlere hizmet içi eğitim nasıl olmalıdır?" sorusuna ait yanıtların kod ve frekansları Çizelge 4'te gösterilmektedir.

\section{Hizmet İçi Eğitim Nasıl Olmalıdır}

Çizelge4.Hizmet içi eğitim nasıl olmalıdır ilişkin kod ve kategoriler

\begin{tabular}{|c|c|c|c|}
\hline \multirow{6}{*}{ 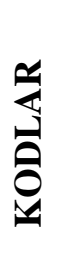 } & & FREKANS & ÖĞRETMENLER \\
\hline & Hizmet İci Eăitim Nasıl Olmalıdır & & \\
\hline & Duayen eğitimciler & 1 & Ö7 \\
\hline & Eğlenceli yapma & 1 & Ö8 \\
\hline & Araştırma sorgulamaya dayalı & 1 & Ö16 \\
\hline & Soru sorma yöntemi & 1 & Ö16 \\
\hline
\end{tabular}

Çizelge 4'te görüldüğü gibi öğretmenler fen eğitiminde yetkin olan kişilerin hizmet içi vermesi gerektiğini, fen bilimleri dersinin daha eğlenceli olmasını içeren bir hizmet içi eğitim olması gerektiğini ve hizmet içi eğitimde öğretmenlerin araştırma sorgulamaya dayalı öğrenme yaklaşımını öğrenmesi gerektiğini belirtmiştir:

"Aslında bakanlık değişmeye çalışıyor ama önünde çok büyük bir engel var, öğretmen kitlesi aslında bunun hizmet içi eğitimle de çözüleceğini sanmıyorum ben. Yani daha öncede 
2006 yılıydı yanılmıyorsam ilk Fen bilgisi dersi, Fen Ve Teknoloji dersi 3 saatten 4 saate çıktığı, Fen ve Teknoloji olduğu zaman yanılmıyorsam 2006-2007 yılıydı tam hatırlamıyorum da, öğretmenleri aldılar topladılar, seminer verdiler 3 gün, gelen, bilgilendirmek için gelen hocadan tutun da gelen öğretmenlere kadar işin gereksiz olduğunu ve bize pek bir şey kazandırmayacağını düşünerek geldiler. Yani aralarda belki birkaç öğretmen ikna olmuştur, kazanmıştır ama işin açıkçası eğitimin bakanlık eliyle olduğu takdirde bunun pek yürüyeceğini zannetmiyorum. Bakanlık bu konuda çünkü görevlendirdiği kişiler, bir görevlendirme yapıyor bakanlık, işte sen gideceksin bu işi yapacaksın diye. Kişi yükümlüdür, olur olmaz gider ama bu işin duayenleri var yani fen eğitimindeki duayen insanlar, bunlar belki iki elin parmaklarını geçmiyor. Onları bir kazandırmak lazım uygulamaya yönelik. Bakanlığın da bu insanları hizmet sektörüne katması, bu eğitime katması şimdilik gözükmüyor yani yapılmadı. Bu yüzden biz, hizmet içi eğitimle de olabileceğini zannetmiyorum.”(Ö7)

"Hizmet içi eğitim olmalı, nasıl olmalı, bence biz hizmet içi eğitimde program tanıtımından ziyade program uygulamasıyla ilgili hizmet içi eğitim almalıyız. Yani bize 5.Sınıfların Fen Bilimleri dersinin 1.ünitesinde 10 kazanım vardır gibi değil de ne yapabiliriz? Nasıl bu dersi daha eğlenceli hale getirebiliriz? Gibi bir hizmet içi eğitim olsa görsel bir şekilde hani mesela atıyorum etkinlikler olsa mesela kitaptaki gibi değil de deney kitleri olsa biz bunları satın alabilsek, ya da uygulayabilsek kendimiz. Bunları hazır olarak verseler bizim için daha yararlı olur. Programı tanıtmayı ben bu tür düşünüyorum yani. Uygulama alanında tanitılmal1.”(Ö8)

\section{SONUÇ VE ÖNERILER}

Yeni fen bilimleri öğretim programının uygulayıcısı olan öğretmenlere tanıtımının yapılması ve programa yönelik uygulama örneklerinin hizmet içi eğitimde öğretmenlerle ortak bir paylaşıma gidilmesi, programın kazanımlarının gerçekleşmesi için büyük önem taşımaktadır. Ayrıca verilecek olan bu hizmet içi eğitimde sınıf yönetimi, materyal hazırlama ve bunun kullanımının yanı sıra öğrenci merkezli öğretim yöntemleri, kazanımları gerçekleştirmeye uygun etkinlik düzenlenmesi ve öğrenmede bireysel farklılıkların dikkate alınmasının önemin vurgulanması programın başarısı için çok önemlidir. Özetle fen bilimleri öğretmenlerinin mesleğinin gerektirdiği bilgi, beceri ve tutumlarına yönelik yeterliklerin kazandırılmasına imkan tanıyı bu özellikleri tüm yaşam boyu süresince geliştirilmesi hizmet öncesi ve hizmet içi eğitimleri sayesinde olmaktadır. Teknolojide yaşanan ve bilginin hızla katlandığı günümüzde bu değişimlere ve gelişen koşullara uyum sağlama açısında hizmet içi eğitim önemlidir. Öğretmenlerin mesleki yaşamlarında başarılı olmalarının temel şartlarından biriside hem hizmet öncesi alınan eğitimin nitelikli olması, hem de hizmet içinde kendilerini sürekli yenilemeleri ve geliştirmeleri bir gerekliliktir. Diğer mesleklere benzer şekilde öğretmenlerin de kendilerini sürekli olarak geliştirmeleri ve mesleklerini verimli olarak yerine getirebilmeleri için alacakları hizmet içi eğitim çok önemlidir (Küçüktepe,2013:27).Kısaca fen bilimleri öğretmenlerinin mesleklerinin gerektirdiği bilgi ve becerileri geliştirme açısında diğer bir deyişle mesleki gelişim için öğretmenlerin alacağı hizmet içi vazgeçilmez bir unsurdur.

Araştırmadan çıkan sonuçlara göre görüşmeye katılan 16 öğretmenden hiç birisi fen bilimleri öğretim programına yönelik hizmet içi eğitim almadığını belirtmiştir. Bunun fen bilimleri öğretim programı dolayısı ile öğretmenlerin öğretim programı konusunda bilgi ve beceri kazanma olanağı verilmediği için büyük bir olumsuzluk olduğu söylenebilir.

Hizmet içi eğitimlerde sadece programın tanıtılmasından öte, fen bilimleri öğretmenlerinin programa yönelik bilgi, beceri ve tutum kazandırılması çok önemlidir. Çünkü programın uygulayıcı olan ögretmenin yeni fen bilimleri ögretim programı konusunda bilgi ve beceri kazandıkça programı tanıyıp benimseyecek ve böylelikle programın daha kolay uygulamaya konulması sağlanabilecektir. Dolayısı ile öğretmenlerin programı tanımıyor olmaları, programı uygulayacak bilgi ve becerilerinde eksikler olabileceği diğer bir deyişle programın başarısı için çok büyük eksiklik olarak nitelendirilebilir. Kısacası program uygulamaya konulmadan önce öğretmenlere programın temel felsefe ve vizyonun tanıtılmasının yanı sıra programın kazanım, içerik, öğretme-öğrenme süreci ve ölçme-değerlendirme boyutlarının sistematik bir şekilde tanıtılmasının yanı sıra program konusunda bilgi, beceri ve tutum geliştirmeye yönelik uygulamalı bir hizmet içi eğitim olanağı sunulmamasının fen bilimleri öğretim programı için çok büyük eksiklik olduğu söylenebilir. 
Görüşme yapılan 16 öğretmenden 4'ü yeni fen bilimleri öğretim programına yönelik hizmet içi verilse derslerine daha kendine güvenerek gireceğini, 3 öğretmen de soru cevap şeklinde, program hakkında bilmedikleri noktalarda sorular sorabilecekleri hizmet içi eğitimin kendilerine yararlı olacağını belirtmişlerdir. Öğretmen görüşlerine dayanarak, öğretmenlerin almış oldukları hizmet içi eğitimde programla ilgili uygulamalı bir hizmet içi eğitimin eksikliğini yaşadıkları söylenebilir. Öğretmenlerden 4'ü yapılan hizmet içi eğitimlerin kendileri için verimsiz olduğunu, yapılan hizmet içi eğitimlerin sadece süre doldurmak amacı ile yapıldığını, bir öğretmen de öğretmenlerin hizmet içi eğitime katılmaya isteksiz olduklarını, yapılan hizmet içi eğitimin köklü değiş̧ime ihtiyaç duyduğunu belirtmiş̧lerdir. Buna göre öğretmenlerin verilen hizmet içi eğitimleri yetersiz olarak gördükleri, hizmet içi eğitimlerde değişiklikler yapılmasını istedikleri ve bu değişimlerden en önemlilerinden bir tanesinin de üniversitelerce verilecek hizmet içi eğitimin olduğu ve bunun da öğretmenlere yarar sağlayabileceği söylenebilir. Ayrıca öğretmenlerin sorunlarının özellikle program hakkında merak ettikleri veya çözüm bulamadıkları problemlerin paylaşıldığı ve sınıflarına aktarabilecekleri uygulamaların yapıldığ 1 hizmet içi eğitim düzenlemesinin öğretmenlere ve dolayısı ile fen bilimleri öğretim programının kazanımlarının uygulanma düzeyinin artırılmasına katkıda bulunabileceği söylenebilir. Özetle öğretmenlerin fen bilimleri öğretim programını yeterince tanımadıkları dolayısı ile öğretmenlerin fen bilimleri öğretim programının felsefesi, yapısı ve programın uygulamasını temel alan bir hizmet içi eğitime ihtiyaç duyduğu söylenebilir. Leeth (1996), Öztürk (2009), Bülbül (2010)'ün araştırma bulgularında da benzer şekilde yeni fen öğretim programı hakkında hizmet içi eğitime ihtiyaç duyulduğu ortaya çıkarılmıştır.

Kazanımların gerçekleşmesi için öğretmenlerin hizmet öncesi ve hizmet içi eğitimler ile uygulamaya konulan programları doğru şekilde anlamaları ve görev yaptıkları okullarında programları uygulamaya koymaları için bilgi ve becerilere sahip olmalıdırlar. Bu sebeple fen bilimleri öğretmenlerinin geliştirilen fen bilimleri öğretim programını uygularken kazanımları gerçekleştirmeye yönelik, öğretmenlerin programları uygulayacak şekilde bilgi ve beceriye yönelik yetiştirilmeleri sağlanmalıdır.

Öğretmenlerin görüşleri incelendiğinde, yapılan hizmet içi eğitimlerin istenilen düzeyde yapılmadığı ve verimsiz geçtiği söylenebilir. Bu sebeple fen bilimleri öğretmenlerine verilen hizmet içi eğitimler öğretmenlerin de önerdiği gibi, üniversitelerle işbirliği içerisinde yapılarak, fen bilimleri öğretim programı uygulamaya konulmadan önce programın uygulama örneklerinin fen bilimleri öğretmenlerine tanıtımı ve paylaşımı yapılmalıdır. Bu bağlamda öğretmenlerin fen bilimleri öğretim programını uygularken yaşadıkları problemlere ve karşılaştıkları güçlüklere çözümler bulanabileceği ve programın uygulanmasına yönelik çeşitli uygulamaların gerçekleştirildiği uygulamalı bir hizmet içi eğitim düzenlenmelidir. Öğretmenler hizmet öncesi ve hizmet süresi boyunca eksiklerini tamamlamak için hizmet içi eğitime gereksinim duymaktadırlar (Selimoğlu ve Yılmaz, 2009: 3). Ayrıca fen bilimleri öğretmen adaylarının fen bilimleri öğretim programının oluşturulmasında etkin olan yaklaşımlara ve bu yaklaşımların uygulama süreçlerine uygun şekilde bilgi ve beceri kazandıracak bir lisans eğitimi verilmesi, fen bilimleri öğretim programının uygulanmasına dolayısı ile kazanımların gerçekleşmesine yardım edecektir. Öğretmenlerin mesleki gelişimlerini artırılmasına yönelik nitelikli hizmet içi eğitim uygulamalarının bazı nedenler dolayısı ile gerçekleştirilemediği ve bu süreçte birçok sorunun yaşandığ ve verilen hizmet içi eğitimin geliştirilmesi gerekliliği diğer araştırmaların sonuçları ile bu araştırma sonuçları arasında benzerlik göstermektedir. (Boydak, 1999;Çevikbaş, 2002). Özetle fen bilimleri öğretmenleri, fen bilimleri programı konusunda kapsamlı ve sürekli bir hizmet içi eğitim sürecinden geçirilmelidir. Bu süreç sadece programın tanıtımını kapsamamalı, öğretmenlerin bilgi, beceri ve tutumlarını geliştirmeye yönelik uygulamalı bir hizmet içi eğitim olmalıdır.

\section{KAYNAKCA}

Boydak, M. (1999). Hizmet içi Ĕgitim Programlarının Değerlendirilmesi, Fırat Üniversitesi Sosyal Bilimler Enstitüsü, Yayımlanmamış Doktora Tezi, Elazı̆̆.

Bülbül, M.F. (2010). İlkögrretim İkinci Kademede Uygulanan Yeni Fen ve Teknoloji Programinın Öğretmen ve Ögrrenci Gözüyle Değerlendirilerek Verimlilik Düzeyinin Belirlenmesi (Bahçelievler Örneği). Yayınlanmamış Yüksek Lisans Tezi. Beykent Üniversitesi, Sosyal Bilimler Enstitüsü, İstanbul.

Çevikbaş, R. (2002). Hizmet içi Eğitim ve Türk Merkezi Yönetimindeki Uygulaması. Nobel Yayın Dağıtım. Ankara. 
Demirel, Ö. (2010). Kuramdan Uygulamaya Eğitimde Program Geliştirme. (12.Basım). Pegem A Yayıncilık, Ankara.

Ekiz, D. (2009). Bilimsel Araştırma Yöntemleri. Anı Yayınc1lık, Ankara.

Erden, M. (1998). Ĕgitimde Program Değerlendirme. (3. Basım). Anı Yayınları, Ankara.

Erişen, Y. (1998). Öğretmenlere yönelik hizmet içi eğitim programların gelişstirmede eğitim ihtiyacı belirleme sürec, Milli Eğitim Dergisi, Say1.140, ss.39-43.

Ertürk, S. (1994). Eğitimde Program Geliştirme. (8.Basım). Meteksan Matbaacılık, Ankara.

Gürbüz,S ve Şahin, F. (2014). Sosyal Bilimlerde Araştırma Yöntemleri. Felsefe, Yöntem, Analiz. Seçkin yayınları.

Johnson, B ve Christiensen, L. (2012). Educational Research Quantative, Qualitative, and Mixed Approaches. (4th Edition). Sage publication.

Küçüktepe, C. (2013). Sinıf ögretmenlerinin hizmet içi eğitim ihtiyaçlarının öğretmen görüşlerine göre belirlenmesi. Abant İzzet Baysal Üniversitesi Eğitim Fakültesi Dergisi, 13(2), 26-43.

Leeth, J.D. (1996). A Study of the Attitude of Students and the Concerns of Teachers toward the Science 1 and Traditional Life Science Curriculum. Unpublished Doctoral Dissertation. University of Texas A\&M: USA.

McDermott J. Beck D. Buffington St.Annas J. Supratikto J. Prenggono D. Ekonomi S. Achadi E. (2001). Two Models Of In-Service Training To Improve Midwifery Skllls: How Well Do They Work?. J Midwifery Womens Health 2001; 46. 217-221.

Miles, M.B. \& Huberman, A.M. (1994). An Expanded Sourcebook Qualitative Data Analysis. Thousans Oaks, Sage Publications, California.

Ornstein, A.C, Hunkins F.P. (2004). Curriculum-Foundatıons, Principles and Issues. (Fourth Edition). Allyn and Bacon, United States.

Öztürk, Ş. (2009). İlköğretim 4. ve 5. Sinıf Fen ve Teknoloji Dersinde Öğretmenlerinin Karşılaştı̆̆ Sorunlar (Denizli İli Örneği). Yayınlanmamış Yüksek Lisans Tezi. Pamukkale Üniversitesi, Sosyal Bilimler Enstitüsü, Denizli.

Selimoğlu, E., Yılmaz, H. B. (2009). Hizmet İçi Eğitimin Kurum ve Çalışanlar Üzerine Etkiler, Paradoks, Ekonomi, Sosyoloji ve Politika Dergisi, ISSN 1305-7979. 5.Y1l, sayi1.1-12.

Sönmez, V. (2008). Program Geliştirmede Öğretmen El Kitabı (14. Baskı). Anı Yayınc1lı, Ankara.

Uşun, S. (2012). Eğitimde Program Değerlendirme Süreçler Yaklaşımlar ve Modeller. Anı Yayıncılık, Ankara.

Yıldırım, A. ve Şimşek, H. (2013). Sosyal Bilimlerde Nitel Araştırma Yöntemleri.(9.Baskı). Seçkin Yayınları, Ankara.

Yürük, N. (2005). An Analysis of The Nature of Students' Metaconceptual Process and the Effectiveness of Metaconceptual Teaching Practices on Students' Conceptuel Understanding of Force and Motion. Unpublished Doctoral Dissertation. University of Ohio State: USA. 